\title{
Media Penginderaan Jauh Berbasis Android dalam Pembelajaran Geografi SMA
}

\author{
Falik Wardana ${ }^{1}$, Sugeng Utaya ${ }^{1}$, Syamsul Bachri ${ }^{1}$ \\ ${ }^{1}$ Pendidikan Geografi-Universitas Negeri Malang
}

\section{INFO ARTIKEL}

\section{Riwayat Artikel:}

Diterima: 01-04-2019

Disetujui: 17-07-2019

Kata kunci:
remote sensing;
geography learning;
high school student;
penginderaan jauh;
pembelajaran geografi;
siswa SMA

siswa SMA

\author{
Alamat Korespondensi: \\ Falik Wardana \\ Pendidikan Geografi \\ Universitas Negeri Malang \\ Jalan Semarang 5 Malang \\ E-mail: falik.wardana@gmail.com
}

\begin{abstract}
This research aims to determine the effectiveness of instructional media on Remote Sensing. Research on this multimedia following the steps Borg and Gall are modified, then have seven steps as needed. The effectiveness of media views of testing of products and comprehension test. The results of field trials demonstrate the effectiveness of the product amounted to $83.1 \%$ comprising the display aspect, materials, operations and language. In addition, the results of comprehension test by the students achieved a score with an average of 81.7 with a minimum completeness criteria 78 . The level of school effectiveness and comprehension test scores can be categorized so effective that multimedia products eligible for use in learning.

Abstrak: Penelitian ini bertujuan untuk mengetahui tingkat keefektifan media pembelajaran pada materi Penginderaan Jauh. Penelitian terhadap multimedia mengikuti langkah-langkah Borg \& Gall yang dimodifikasi, kemudian dipilih tujuh langkah disesuaikan dengan kebutuhan. Tingkat keefektifan media dilihat dari uji coba produk dan tes pemahaman. Hasil uji coba lapangan menunjukkan tingkat keefektifan produk sebesar $83,1 \%$ yang terdiri dari aspek tampilan, materi, pengoperasian dan bahasa. Selain itu hasil tes pemahaman oleh siswa mencapai skor dengan rata-rata sebesar 81,7 dengan kriteria ketuntasan minimal sekolah 78. Tingkat kefektifan dan skor tes pemahaman tersebut dapat dikategorikan sangat efektif sehingga produk multimedia layak digunakan dalam pembelajaran.
\end{abstract}

Penginderaan Jauh merupakan salah satu materi dalam geografi teknik. Materi Penginderaan Jauh penting untuk dipelajari karena sangat dibutuhkan dalam mengkaji fenomena keruangan. Pernyataan ini berbanding terbalik dengan hasil penelitian (Ningsih, Suwarni, \& Utami, 2016) mengungkapkan bahwa materi penginderaan jauh adalah salah satu materi yang relatif sulit dibandingkan dengan materi lain. Hal ini terjadi karena pembelajaran Penginderaan Jauh secara umum masih dijelaskan hanya pada teori dan konsep. Materi Penginderaan Jauh tidak akan mudah dipahami jika hanya dijelaskan pada teori tanpa diikuti dengan praktik. Kesulitan pada materi penginderaan jauh akan berpengaruh terhadap pencapaian tujuan pembelajaran. Hal ini bagi sebagian besar guru geografi di Indoensia merupakan permasalahan yang hampir sama pada materi Penginderaan Jauh. Hasil seminar nasional oleh (Andrasmoro \& Ratri, 2010) membuktikan bahwa terdapat banyak kendala yang dihadapi guru dan siswa dalam kegiatan belajar mengajar, salah satunya yakni terkait penguasaan teknik dan media pembelajaran tentang penginderaan jauh. Penelitian lainnya oleh (Zain, Utami, \& Murtini, 2012) menyatakan bahwa sebagian besar guru geografi SMA mengalami kesulitan dalam mengajarkan materi Penginderaan Jauh dan media yang digunakan. Berdasarkan seminar dan penelitian tersebut menunjukkan bahwa sebagian besar guru mengalami kesulitan mengajarkan materi Penginderaan Jauh, terlebih media yang digunakan.

Terdapat dua permasalahan utama dalam pembelajaran materi Penginderaan Jauh. Permasalahan tersebut yakni (1) guru geografi mengalami kesulitan menjelaskan materi Penginderaan Jauh pada saat pembelajaran, (2) guru geografi kesulitan dalam memilih media pembelajaran yang digunakan. Pada umumnya, guru hanya menguasai teori Penginderaan Jauh, namun belum bersifat aplikatif bagi siswa. Hal ini membuat pembelajaran di kelas hanya menggunakan media buku teks dan media seadanya, seharusnya untuk dapat membangkitkan motivasi belajar siswa dan pembelajaran yang efektif dibutuhkan media pembelajaran (Prananta, Setyosari, \& Santoso, 2017). Sejalan dengan pendapat tersebut (Lestari, Utaya, \& Susilo, 2018) menyatakan bahwa pembelajaran geografi di SMA kurang memotivasi karena belum adanya media pembelajaran yang tepat. 
Media pembelajaran Penginderaan Jauh berbasis android dapat digunakan sebagai alternatif yang efektif untuk membantu pemahaman siswa terhadap materi. Efektifnya media pembelajaran penginderaan jauh terletak pada kemudahan pengoperasian pada saat digunakan siswa. Selain itu, media juga disesuaikan dengan kebutuhan siswa untuk mewadahi tipe belajar dan kemampuan yang berbeda-beda. Hal tersebut sesuai dengan pendapat (Akbar, 2016) yang menyatakan media berfungsi sebagai alternatif sumber belajar yang dapat digunakan siswa secara mandiri sehingga memfasilitasi belajar siswa sesuai tipe dan kemampuannya.

Media pembelajaran penginderaan jauh berbasis android selain memberikan manfaat kemudahan memahami materi, penggunaan media ini juga memungkinkan terdapat manfaat lain, yakni (1) membantu siswa berpikir secara sisematis, (2) menarik minat belajar siswa, dan (3) mempersingkat waktu memahami materi. Beberapa manfaat tersebut membuat siswa dapat belajar dengan mudah dan menyenangkan. Hasil penelitian oleh (Anditasari, Martutik, \& Andajani, 2018; Arsyad, 2013; Irmawati, Degeng, \& Djatmika, 2017; Musfiqon, 2012) menyatakan bahwa media menciptakan pembelajaran yang menyenangkan, menarik, dan efektif serta membantu kebutuhan siswa memahami materi.

Media pembelajaran penginderaan jauh merupakan integrasi dari beberapa kegiatan yang terdiri dari penjelasan materi, praktikum sederhana, dan evaluasi. Pada penjelasan materi, media digunakan sebagai perantara penyampaian pesan dari guru ke siswa yang tentunya memuat materi yang akan disampaikan. Kegiatan praktikum sederhana merupakan wadah untuk melatih keterampilan siswa sehingga materi yang dipelajari dapat lebih terasah. Kegiatan evaluasi dilakukan untuk menguji kemampuan siswa dalam memahami materi. Didukung dengan beberapa kegiatan dalam media pembelajaran, maka dapat membuat siswa tertarik belajar geografi dan membantu memahami materi penginderaan jauh.

Tujuan dari penelitian ini dilakukan adalah untuk mengetahui tingkat keefektifan media sehingga dapat dimanfaatkan dalam pembelajaran. Media pembelajaran yang dikembangkan menggunakan Construct 2 ini berbentuk aplikasi android yang sangat mudah digunakan. Untuk dapat mengetahui keefektifan produk media digunakan model penelitian dan pengembangan (Gall, Borg, \& Gall, 1996). Penggunaan model (Gall et al., 1996) berdasarkan pada pertimbangan bahwa (1) model relatif sederhana, namun tahapan dan komponennya rinci sampai pada produk, (2) berorientasi pada tujuan, (3) menampilkan sistem evaluasi yang variatif, dan (4) terdapat langkah revisi.

\section{METODE}

Penelitian ini menggunakan metode survei berbantuan angket tanggapan kepada siswa setelah menggunakan media. Uji coba media dilaksanakan di SMAN 7 Banjarmasin mulai tanggal 8-11 Januari 2019. Subjek uji coba terdiri atas 1 orang guru geografi dan 34 orang siswa kelas XII pada materi Penginderaan Jauh.

Instrumen pengumpulan data yang digunakan terdiri dari angket tanggapan guru dan siswa serta tes pemahaman untuk melihat keefektifan produk multimedia. Keefektifan media berdasarkan tanggapan siswa dinilai dari beberapa aspek, meliputi aspek tampilan, materi, pengoperasian dan bahasa, sedangkan tanggapan guru dinilai untuk melihat media dari aspek kesesuaian dengan tujuan, praktis dan luwes, serta pengelompokan sasaran.

Teknik analisis yag digunakan untuk menilai tanggapan siswa dan guru menggunakan analisis dalam bentuk skor yang menunjukkan kriteria menggunakan skala Likert. Data hasil uji coba disajikan dalam jumlah skor keseluruhan dan skor dari setiap indikator. Skor hasil uji coba kemudian dimasukkan dalam kriteria yang digunakan dalam jabaran tabel persentase. Berikut kriteria tingkat keefektifan produk media pembelajaran Penginderaan Jauh dapat dikaji pada tabel 1. Data tes pemahaman siswa diperoleh melalui skor/nilai hasil tes pemahaman dan berdasarkan KKM Geografi di SMAN 7 Banjarmasin yaitu 78 . Tingkat pemahaman rata-rata dihitung dengan rumus berikut.

Keterangan:

$$
\text { Mean }=\frac{\sum x}{\mathrm{n}}
$$

$\sum \mathrm{x}=$ jumlah nilai keseluruhan

$\mathrm{n}=$ jumlah siswa.

Tabel 1. Persentase Penjabaran Hasil Uji Coba

\begin{tabular}{cl}
\hline Tingkat Persentase (\%) & \multicolumn{1}{c}{ Kriteria } \\
\hline $81-100$ & Media sangat efektif dan dapat digunakan untuk pembelajaran \\
\hline $61-80$ & Media efektif dan dapat digunakan untuk pembelajaran \\
\hline $41-60$ & Media cukup efektif, tetapi belum memenuhi kritetia untuk digunakan dalam pembelajaran \\
\hline $21-40$ & Media tidak efektif dan tidak dapat digunakan untuk pembelajaran \\
\hline $0-20$ & Media sangat tidak efektif dan tidak dapat digunakan dalam pembelajaran \\
\hline
\end{tabular}




\section{HASIL}

Data hasil uji coba produk yang dilakukan pada 34 orang siswa dan 1 guru geografi di SMA Negeri 7 Banjarmasin dapat dilihat pada skor garis skala berikut (gambar 1).

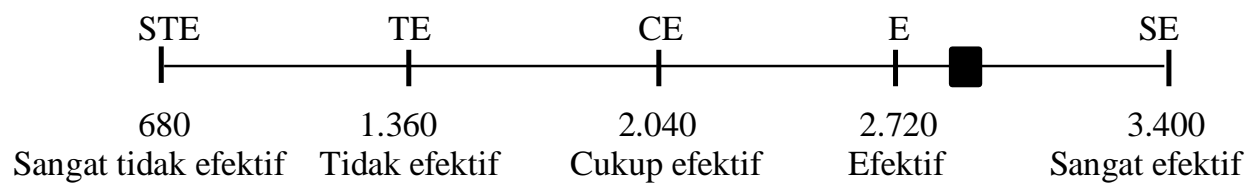

Keterangan: Letak irisan hasil uji coba, diperoleh skor sebesar 2.826 (kriteria diatas efektif dan dibawah sangat efektif)

\section{Gambar 1. Garis Skala Hasil Uji Coba}

Hasil uji coba produk dilapangan menunjukkan bahwa jumlah skor keseluruhan responden mencapai 2.826. Berdasarkan garis skala, skor sebesar 2.826 menunjukkan bahwa media berapa diantara kriteria efektif dan sangat efektif. Interpretasi skor tersebut disajikan dalam bentuk tabel yang menunjukkan persentase skor untuk mempertegas sajian. Tabel 2 menunjukkan hasil penilaian siswa dan guru terhadap media.

Tabel 2. Jabaran Data Uji Coba Produk

\begin{tabular}{|c|c|c|c|c|c|c|c|}
\hline \multicolumn{4}{|c|}{ Angket Tanggapan Siswa } & \multicolumn{4}{|c|}{ Angket Tanggapan Guru } \\
\hline No & Aspek & Nilai Rata-rata & Kriteria & No & Aspek & Nilai Rata-rata & Kriteria \\
\hline 1 & Tampilan & 80,9 & Sangat Efektif & 1 & $\begin{array}{l}\text { Kesesuaian dengan } \\
\text { tujuan }\end{array}$ & 86,6 & $\begin{array}{l}\text { Sangat } \\
\text { Efektif }\end{array}$ \\
\hline 2 & Materi & 85,7 & Sangat Efektif & 2 & $\begin{array}{l}\text { Praktis, luwes, dan } \\
\text { kebertahanan }\end{array}$ & 85 & $\begin{array}{l}\text { Sangat } \\
\text { Efektif }\end{array}$ \\
\hline 3 & Pengoperasian & 82,8 & Sangat Efektif & 3 & $\begin{array}{l}\text { Pengelompokan } \\
\text { sasaran }\end{array}$ & 73,3 & Efektif \\
\hline 4 & Bahasa & 83,2 & Sangat Efektif & & & & \\
\hline & or total nilai rata-rata & 332,6 & & $\sum \mathrm{Sl}$ & total nilai rata-rata & 244,9 & \\
\hline & $\begin{array}{l}\text {-rata skor total } \\
\text { pat aspek }\end{array}$ & 83,1 & Sangat Efektif & $\begin{array}{l}\text { Rat } \\
\text { asp }\end{array}$ & ata skor total ketiga & 81,6 & $\begin{array}{l}\text { Sangat } \\
\text { Efektif }\end{array}$ \\
\hline
\end{tabular}

Berdasarkan tabel 2 pada aspek tanggapan siswa dapat dilihat bahwa secara keseluruhan kualitas produk menunjukkan kualifikasi sangat efektif. Hal tersebut ditunjukkan oleh persentase skor yang didapat sebesar 83,1\% dari empat aspek. Persentase tersebut menjelaskan bahwa produk yang telah dikembangkan sudah baik dari empat aspek yang dinilai. Hasil paling rendah terdapat pada indikator tampilan dengan persentase skor 80,9\%. Hal tersebut dikarenakan ketika uji coba lapangan terdapat beberapa faktor yang menyebabkan responden tidak terlalu fokus pada tampilan media. Adapun faktor-faktor tersebut berupa (1) tidak seluruh siswa menggunakan smartphone berbasis android, (2) terbatasnya responden untuk melihat tampilan karena layar smartphone yang tidak terlalu besar, dan (3) suasana yang kurang kondusif saat uji coba produk.

Hasil tanggapan guru pada tabel 2 dapat dilihat bahwa secara keseluruhan dari tiga indikator, produk menunjukkan kualifikasi sangat efektif. Hal tersebut ditunjukkan oleh tingkat persentase skor yang didapat sebesar $81,6 \%$. Skor terendah dari tiga indikator pada angket tanggapan guru terdapat pada indikator pengelompokan sasaran yang memiliki skor $73,3 \%$. Selanjutnya, yakni tes pemahaman siswa yang terdiri dari soal pilihan ganda. Tes pemahaman dilakukan untuk mengetahui tingkat pemahaman materi Penginderaan Jauh setelah menggunakan media. Tes pemahaman diikuti oleh 34 siswa yang terdiri dari 10 butir soal.

Hasil uji coba lapangan menunjukkan bahwa mayoritas siswa dapat mempelajari materi dalam media. Hal ini dibuktikan dengan nilai rata-rata yang diperoleh siswa setelah mengerjakan soal tes. Nilai rata-rata siswa dari soal tes pemahaman yakni 81,7. Hasil nilai tes pemahaman siswa dapat dilihat pada tabel 3.

Tabel 3. Hasil Tes Pemahaman Siswa SMAN 7 Banjarmasin Kelas XI IIS 2

\begin{tabular}{lccccc}
\hline \multirow{2}{*}{ Kelas } & \multirow{2}{*}{ KKM } & \multicolumn{2}{c}{ Pencapaian Kelas } & \multicolumn{2}{c}{ Pencapaian Individu } \\
\cline { 3 - 6 } & & Nilai Rata-rata & Ketuntasan & $\sum$ Siswa Tuntas & $\sum$ Siswa Tidak Tuntas \\
\hline XII IIS 2 & 78 & 81,7 & Mencapai KKM & 29 & 5 \\
\hline
\end{tabular}


Berdasarkan tabel 3 dan merujuk pada kriteria ketuntasan minimal di SMAN 7 Banjarmasin yaitu 78, diketahui dari 34 siswa yang diuji coba, sebanyak 5 siswa memperoleh skor tingkat pemahaman $\leq 78$. Selebihnya 29 siswa memperoleh skor tingkat pemahaman 78-100. Hasil tes menunjukkan secara mayoritas siswa sudah menguasai materi dengan baik dan dapat mencapai kriteria ketuntasan belajar. Hal ini membuktikan bahwa penggunaan media dapat membantu siswa memahami materi Penginderaan Jauh.

\section{PEMBAHASAN}

Hasil uji coba produk di SMA Negeri 7 Banjarmasin menunjukkan bahwa media pembelajaran Penginderaan Jauh berbasis android ini sangat efektif dan dapat dimanfaatkan dalam pembelajaran geografi. Keefektifan media pembelajaran tersebut didukung oleh tanggapan seluruh siswa dan guru yang tertarik terhadap media pembelajaran tersebut. Hal ini sesuai hasil penelitian (Umar, 2017) menyatakan media pembelajaran pada hakekatnya bertujuan untuk meningkatkan efisiensi dan efektivitas pembelajaran. Selain itu (Rahmawati, Roekhan, \& Nurchasanah, 2016) juga menyatakan agar kegiatan pembelajaran berlangsung dengan efektif, guru harus mampu menyediakan bahan ajar yang sesuai dengan kebutuhan dan media pembelajaran yang dapat membantu menyampaiakan materi serta keterampilan kepada siswa.

Tanggapan seluruh siswa terhadap keempat aspek juga memengaruhi keefektifan media. Pada setiap aspek memiliki tinjauan penilaian yang berbeda. Aspek tampilan meninjau mengenai desain tampilan dan tingkat kejelasan gambar pada media pembelajaran. Pada aspek materi meninjau tentang tingkat kesesuaian antara materi dengan kebutuhan siswa. Sejalan dengan pendapat (Hayati, Utaya, \& Astina, 2016) menjelaskan bahwa materi harus disesuaikan kebutuhan dan lingkungan sekitar agar bermanfaat bagi kehidupan siswa. Selain itu, pendapat tersebut juga didukung oleh pernyataan (Irmawati, et al., 2017) bahwa media menciptakan pembelajaran yang menyenangkan, menarik dan efektif serta membantu kebutuhan siswa memahami materi. Ditinjau dari pernyataan dan manfaat dengan adanya media pembelajaran, aspek tampilan dan materi pada media penginderaan jauh sudah sesuai karena siswa mudah memahami materi dan menarik untuk belajar geografi.

Aspek selanjutnya yakni pengoperasian dan bahasa. Aspek pengoperasian meninjau tentang kemudahan media penginderaan jauh digunakan baik secara mandiri maupun pada saat di kelas. Pada aspek bahasa meninjau tentang tingkat kejelasan teks dan bahasa yang komunikatif sehingga mudah dimengerti siswa. Hal ini sesuai karena media pembelajaran mampu mewadahi siswa untuk belajar mandiri serta memperjelas penyajian materi agar tidak terlalu bersifat verbalistis (Putri, 2015). Sejalan dengan pendapat tersebut, Levie \& Lents dalam (Kustandi \& Sujipto, 2013) media berfungsi memudahkan siswa memahami teks, sehingga siswa yang lemah membaca mampu mengorganisasikan informasi dalam teks dan mengingatnya kembali. Berdasarkan hasil tangapan siswa dan pernyataan pada kedua apsek tersebut, media pembelajaran mampu memberikan kemudahan untuk siswa belajar mandiri dan memahami karena bahasa yang digunakan komunikatif.

Keefektifan media pembelajaran Penginderaan Jauh berbasis android ini terlihat dari kemudahan pengoperasian media oleh siswa. Kemudahan tersebut dilihat dari media pembelajaran yang dapat langsung digunakan setelah di instal dan juga menyenangkan bagi siswa. Menurut (Kustandi \& Sujipto, 2013) bahwa media memberikan ketertarikan dari tampilan, memberikan ketahanan siswa untuk belajar, pengalaman baru, serta pengorganisasian informasi secara visual agar mudah diingat. Didukung oleh hasil penelitian (Chumaidi, Sulton, \& Sulthoni, 2016) menyatakan banyak sekolah di Indonesia memanfatkan media pembelajaran karena cukup efektif, efisien, dan menarik untuk digunakan sebagai sumber belajar. Hasil tanggapan siswa dan pendapat tersebut menunjukkan bahwa penggunaan media penginderaan jauh sangat efektif apabila digunakan dalam pembelajaran. Hal ini mengacu pada kemudahan dan kemenarikan dari media pada saat digunakan oleh siswa.

Media pembelajaran penginderaann jauh berbasis android terdiri dari beberapa kegiatan. Beberapa kegiatan tersebut yakni penjelasan materi, praktikum sederhana yang membantu siswa memahami materi, dan juga evaluasi untuk melihat tingkat pemahaman siswa setelah menggunakan media. Seperti yang dikemukakan oleh (Sanjaya, 2012) terkait media yang digunakan harus sesuai materi, minat, kebutuhan dan memperhatikan efektivitasnya sehingga mampu mencapai tujuan pembelajaran. Selain itu, (Afandi, Mardji, \& Wibawanto, 2017) penggunaan media membuat materi yang sulit dapat disampaikan dengan mudah sehingga tidak terjadi kesalahan konsep. Dengan demikian, media penginderaan jauh merupakan sebuah media yang lengkap karena mampu menyajikan berbagai kegiatan dan konsep materi yang benar sehingga dapat mencapai tujuan pembelajaran.

Penggunaan media pembelajaran membuktikan bahwa media memiliki peran penting dalam pembelajaran. Tetapi hal tersebut tidak dapat mendasari bahwa guru dapat menggunakan segala macam media untuk pembelajaran. Terdapat beberapa hal yang harus diperhatikan untuk memilih media yang sesuai. Seorang guru dalam merancang perangkat pembelajaran di kelas harus memerhatikan keterkaitan antara media yang digunakan dengan materi yang akan dibelajarkan sehingga tujuan dari pembelajaran yang dirumuskan di awal pembelajaran dapat dicapai secara optimal (Wulandari, Susilo, \& Kuswandi, 2017). Didukung oleh (Arsyad, 2013) menjelaskan kriteria yang perlu diperhatikan dalam memilih media yakni sesuai dengan tujuan dan materi, praktis, luwes, bertahan serta mudah digunakan. Oleh karena itu, media penginderaan jauh selain memperhatikan kemenarikan juga menekankan pada materi dan kemudahan pada saat digunakan. 
Media pembelajaran penginderaan jauh mampu memengaruhi hasil belajar siswa. Hasil penelitian Felton dalam (Asyhar, 2011) menunjukkan bahwa penggunaan media dalam pembelajaran secara signifikan mampu meningkatkan hasil belajar. Collins dalam (Asyhar, 2011) juga menunjukkan bahwa penggunaan media audio dan video berpengaruh terhadap hasil belajar. Berdasarkan paparan dan hasil tes pemahaman terkait media mampu membawa pengaruh baik untuk membantu pemahaman siswa. Media pembelajaran juga dapat dipandang sebagai alternatif yang efektif untuk membantu pemahaman siswa.

Penggunaan media pembelajaran penginderaan jauh dapat menjadi stimulus belajar yang memiliki manfaat untuk membantu siswa mengenali, memahami, dan menganalisis informasi secara mandiri. Hal ini dapat memberikan pengalaman dan informasi tambahan sehingga menjadikan guru bukan satu-satunya sumber belajar dan penyebab siswa belajar. Dengan adanya media pembelajaran peserta didik lebih mudah untuk mencari dan mendapatkan sumber informasi yang dibutuhkan tanpa tergantung dengan sumber belajar yang diberikan guru (Sasongko \& Suswanto, 2017). Media juga dapat berperan sebagai alat bantu memvisualisasikan materi serta mengatasi keterbatasan pengalaman yang dimiliki oleh siswa (Triastuti \& Irawan, 2017). Penggunan media penginderaan jauh dapat menjadi wadah untuk belajar mandiri dan mengatasi keterbatasan pada saat siswa belajar.

Selain penggunaan mandiri, pemanfaatan media penginderaan jauh dalam kelas juga dapat membantu permasalahan pemahaman materi dan memotivasi siswa. Penggunaan media dalam proses pembelajaran membuat kegiatan belajar mengajar di kelas berlangsung menarik, menyenangkan, dan variatif. Pengaplikasian media yang beragam dan sesuai dengan kebutuhan dapat melatih kemampuan peserta didik dalam menyelesaikan berbagai kesulitan-kesulitan yang mereka hadapi terkait penguasaan pengetahuan dan keterampilan (Anditasari et al., 2018). Sejalan dengan pendapat tersebut, (Ahda, 2016) menyatakan dengan menghadirkan media yang menarik di kelas, siswa akan mudah memahami materi karena mereka termotivasi. Hal ini membuktikan bahwa penggunaan media memiliki peran yang penting dalam kelas.

Hasil tanggapan siswa dan juga guru, menunjukkan bahwa media pembelajaran Penginderaan Jauh mampu menarik dan memberikan variasi berbeda dalam pembelajaran. Secara umum, siswa terlihat tertatik dan antusias saat menggunakan media tersebut. Terlebih media juga menampilkan kegiatan praktik yang jarang dilakukan oleh siswa sebelumnya. Apalagi pada materi Penginderaan Jauh masih belum banyak media pembelajaran yang bisa dimanfaatkan oleh siswa maupun guru. Oleh karena itu, media pembelajaran Penginderaan Jauh berbasis android ini dapat menjadi sumber atau sarana yang efektif dalam pembelajaran geografi baik di kelas maupun secara mandiri.

Berdasarkan hasil dan pembahasan yang telah diuraikan, maka efektif dan kebermanfaatan media pembelajaran dapat dilihat dari tanggapan siswa maupun guru pada saat digunakan. Efektif dan kebermanfaatan media pembelajaran ditinjau dari berbagai aspek yang meliputi aspek tampilan, materi, pengoperasian, dan bahasa. Untuk itu, pemilihan media pembelajaran yang baik harus dapat memenuhi kriteria efektif dan sesuai dengan kebutuhan siswa.

\section{SIMPULAN}

Media pembelajaran Penginderaan Jauh ini sangat efektif dan dapat dimanfaatkan dalam pembelajaran. Keefektifan media pembelajaran didasarkan pada hasil tanggapan siswa dan guru serta hasil tes pemahaman. Hasil tanggapan siswa dan guru memperoleh skor $83,1 \%$ dan $81,6 \%$, yang memenuhi kriteria sangat efektif terhadap keempat aspek yang dinilai. Keempat aspek tersebut meliputi aspek tampilan, materi, pengoperasian, dan bahasa.

Keefektifan media ditunjukkan dari skor rata-rata tes pemahaman siswa yang mencapai 81,7 dimana kriteria ketuntasan minimal bidang studi Geografi di SMAN 7 Banjarmasin yakni 78. Hal tersebut menunjukkan bahwa media pembelajaran yang dikembangkan sudah sesuai dan memudahkan siswa dalam memahami materi Penginderaan Jauh.

Berdasarkan kesimpulan tersebut, disarankan bagi guru dan siswa untuk menggunakan media khususnya Penginderaan Jauh baik secara mandiri maupun di kelas agar tercipta variasi pembelajaran. Bagi peneliti selanjutnya, diharapkan dapat mengembangkan media pembelajaran pada materi geografi teknik lain, seperti SIG dan pemetaan untuk melengkapi media dan dapat dimanfaatkan dalam pembelajaran geografi SMA.

\section{DAFTAR RUJUKAN}

Afandi, A. A., Mardji., \& Wibawanto, S. (2017). Pembelajaran Berbantu Komputer pada Mata Pelajaran Sensor dan Aktuator untuk Meningkatkan Pengetahuan dan Keterampilan Siswa SMK Kelas XI Teknik Elektronika Industri. Jurnal Pendidikan: Teori, Penelitian, dan Pengembangan, 2(2), 206-211.

Ahda, Z. Z. (2016). Developing Audio-visual Media of Fables and Folktales for English Speaking Activity In Junior High School Classroom. Jurnal Pendidikan: Teori, Penelitian, dan Pengembangan, 1(10), 1969-1980.

Akbar, T. N. (2016). Pengembangan Multimedia Interaktif IPA Berorientasi Guide Inquiry pada Materi Sistem Pernapasan Manusia Kelas V SDN Kebonsari 3 Malang. Jurnal Pendidikan: Teori, Penelitian, dan Pengembangan, 1(6), $1120-1126$.

Anditasari, R., Martutik, M., \& Andajani, K. (2018). Pengembangan Media Berbasis Permainan Edukatif pada Pembelajaran Menulis Teks Deskripsi. Jurnal Pendidikan: Teori, Penelitian, dan Pengembangan, 3(1), 107-114. 
Andrasmoro, D., \& Ratri, D. A. (2010). Kendala Guru Geografi dalam Pengembangan Pembelajaran Penginderaan Jauh (Remote Sensing) dan SIG (Sistem Informasi Geografi) di Lingkungan SMA Kelas XII Kabupaten Sragen.

Arsyad, A. (2013). Media Pembelajaran. Jakarta: Raja Grafindo Persada.

Asyhar, R. (2011). Kreatif Mengembangkan Media Pembelajaran. Jakarta: Gang Persada (GP) Press.

Chumaidi, A. C., Sulton, S., \& Sulthoni, S. (2016). Pengembangan Multimedia Interaktif Mata Pelajaran Biologi Kelas X Semester II di SMA Wahid Hasyim Model Lamongan. Jurnal Pendidikan: Teori, Penelitian, dan Pengembangan, 1(3), 507-520.

Gall, M. D., Borg, W. R., \& Gall, J. P. (1996). Educational research: An introduction. London: Longman Publishing.

Hayati, W. I., Utaya, S., \& Astina, I. K. (2016). Efektivitas Student Worksheet Berbasis Project Based Learning dalam Menumbuhkan Kemampuan Berpikir Kritis Siswa pada Mata Pelajaran Geografi. Jurnal Pendidikan: Teori, Penelitian, dan Pengembangan, 1(3), 468-474.

Irmawati, I., Degeng, I. N. S., \& Djatmika, E. T. (2017). Multimedia Pembelajaran IPS Materi Kondisi Geografis Wilayah Indonesia pada Siswa Kelas V Sekolah Dasar. Jurnal Pendidikan: Teori, Penelitian, dan Pengembangan, 2(5), 604-609.

Kustandi, C., \& Sujipto, B. (2013). Media Pembelajaran. Bogor: Ghalia Indonesia.

Lestari, W. W., Utaya, S., \& Susilo, S. (2018). Efektivitas Media Pembelajaran Geography Critical Game Berbasis Komputer Dalam Pembelajaran Geografi SMA. Jurnal Pendidikan: Teori, Penelitian, dan Pengembangan, 3(10), $1265-1269$.

Musfiqon, H. M. (2012). Pengembangan Media dan Sumber Pembelajaran. Jakarta: Prestasi Pustakaraya.

Ningsih, N. A., Suwarni, N., \& Utami, R. K. S. (2016). Kendala Guru Mengajar Penginderaan Jauh di SMA Negeri 1 Gedong Tataan Tahun Pembelajaran 2014-2015. JPG (Jurnal Penelitian Geografi), 4(2), 1-10.

Prananta, Y. R., Setyosari, P., \& Santoso, A. (2017). Pengembangan Media Boneka Tangan Berbasis Digital Storytelling. Jurnal Pendidikan: Teori, Penelitian, dan Pengembangan, 2(5), 627-636.

Putri, A. E. (2015). Pengembangan Multimedia Peta Tematik Digital pada Mata Pelajaran Geografi Kelas X SMA untuk Topik Mitigasi dan Adaptasi Bencana Alam. Tesis tidak diterbitkan. Universitas Negeri Malang, Malang.

Rahmawati, I. S., Roekhan, R., \& Nurchasanah, N. (2016). Pengembangan Media Pembelajaran Menulis Teks Fabel dengan Macromedia Flash bagi Siswa SMP. Jurnal Pendidikan: Teori, Penelitian, dan Pengembangan, 1(7), 1323-1329.

Sanjaya, W. (2012). Media Komunikasi Pembelajaran. Jakarta: PT. Fajar Interpratama Mandiri.

Sasongko, G. W., \& Suswanto, H. (2017). Pengembangan Game sebagai Media Evaluasi Pembelajaran pada Mata Pelajaran Perakitan Komputer Kelas X Jurusan Multimedia. Jurnal Pendidikan: Teori, Penelitian, dan Pengembangan, 2(7), 10171023.

Triastuti, D., \& Irawan, E. B. (2017). Pengembangan Media Papan Permainan Panjat Pinang. Jurnal Pendidikan: Teori, Penelitian, dan Pengembangan, 2(10), 1344-1350.

Umar, U. (2017). Media Pendidikan: Peran dan Fungsinya dalam Pembelajaran. Tarbawiyah Jurnal Ilmiah Pendidikan, 11(01), 131-144.

Wulandari, R., Susilo, H., \& Kuswandi, D. (2017). Penggunaan Multimedia Interaktif Bermuatan Game Edukasi untuk Meningkatkan Aktivitas dan Hasil Belajar Siswa Sekolah Dasar. Jurnal Pendidikan: Teori, Penelitian, dan Pengembangan, 2(8), 1024-1029.

Zain, I. M., Utami, W. S., \& Murtini, S. (2012). Pelatihan Pembelajaran SIG dan PJ bagi Guru Pamong PPG Prodi Pendidikan Geografi FIS Universitas Negeri Surabaya. Jurnal Pendidikan Geografi, 13(1), 1-6. 